more or less irregular : just now, however, it is clrawing so long a breath that one fears that its last message has been carried. We are now in the middle of December and the Octohes number has not yet been heard of ! ANGELUS

\section{The Pronunciation of Chinese Names}

SOMEWHAT after date, I heg to return to the subject of Angloand Franco-Chinese orthography, referred to in NAruRE, vol. $\because x x$. p. 592. In a short paper of mine published in the Proceed ings of the Royal Geographical Society, vol. xxii. No. 6, 1877, I alluded to the desirability of a uniform or fixed "Roman equivalent" for Chinese characters standing for names of places, \&c. I inclose a copy of this paper for insertion if desirable. To my mind the Italian vowels, \&c., come nearest to the sounds of the Chinese characters. Tung-King, meaning "Eastern Capital," is the usually accepted form of Tonquin, or Ton-Kin, the terminal $g$ being but slightly sounded. Shang-hai, the "Upper Sea," or the place "of going up to the sea," should be pronounced with the $g$, and is so spoken (Shanghai) by English and American authorities. I)r. Wells Williams has, I believe, in manuscript a standard Chinese Gazetteer of the World, in which all proper names likely to be used in telegraphy, newspapers, \&c., are smoothly transliterated into Chinese characters. For translations from Chinese it is very necessary to adopt some such plan as Dr. Hunter has suggested for Indian names. Although his plan has come too late into the field to induce people to spell Calcutta as Kolkata, this is hardly the case as yet with Chinese names. 'The old native names of places should always be literally preserved. How much more beautiful is the old Franco-Indian name Stadaconda than Quebec for the scene of the death of Wolfe ! I should be glad to co-operate or correspond with any interested in this matter, so prominent and important at the present juncture.

F. PORTER SMith

Hillworth House, Shepton Mallet, December I2

\section{EXPLORATIONS IN ICELAND 1 \\ THE LAVA DESERT OF ÓDÁðAHRAUN}

$$
\text { III. }
$$

THE second part of my programme included the exploration of the western and southern portions of the Ódáðahraun Desert. In this journey I spent a fortnight during the latter half of August, a thoroughly rough and arduous time, on account of the very unsettled weather alternating between cold and rain, tempestuous gales, snowstorms, and sand-hurricanes. My journey extended to 240 English miles, but only two oases of grass were discovered the whole way. Along the skirts of Vatnajökul, throughout the whole extent of the lavas and sand plateaus which form the northern fringe or border intersecting it from Ódátahraun, not one single blade of grass, nay, not even signs of mosses or lichens, are anywhere discoverable, hence we were obliged to provide ourselves with fodder for the horses in the shape of hay, oats, and maize dough.

The results of the journey are in every way as good as, under the circumstances, I could have anticipated. Now at last the whole of Odádahraun, with its surrounding wildernesses, has been explored. The weather was often enough sufficiently clear and fair to give me an opportunity to note all that required surveying. The few who have travelled over various parts of these deserts before me have seen next to nothing, on account of bad weather. Odádahraun, as stated in a former letter, is the largest lavadesert not only in Iceland, but in all Europe; the main portion of it has been formed by volcanic activity in Iceland in prehistoric times ; but since the discovery of the island, even down to our own day, the region has witnessed a succession of eruptions. The various lava-flats form onc plateau, the bounds of which are determined on the east by Jökulsá in Axarfjörd, south by Vatnajökul, west by Skjálfandafljót, north by Mývatn. At its southern extremity it rises to 3200 , at its northern to from 1400 to I 500, feet above the level of the sea. Altogether I took

$$
{ }^{x} \text { Continued from vol. xxx. p. } 585 \text {. }
$$

there about two hundred barometric and trigonometrical elevations and surveys. The separate lava-flats are due to about twenty separate volcanoes, honeycombed by hundreds of craters. Several of the separate lavas are, to the extent of many tens of square miles, one unbroken flat lava-field as it were; others, again, all torn up and disrupted, in some cases almost, in others entirely, impassable. The substratum of Ódádahraun is palagonitetuff and breccia, over the top of which is spread the doleritic lava, the origin of which dates from before the Glacial period. Above all the modern lavas have flowed. All the mountains that tower above the lava consist of palagonite breccia ; along their roots and spurs are frequently found rows of craters, as well as those shield-fashioned volcanoes from which the lavas have welled out. The largest volcanoes have been built up entirely by lava-floods, which have flowed successively over each other, so as to form enormous convexities presenting an equal inclination to every side, but so slight as to amount to only a few degrees. This kind of volcano, which in the north country is generally designated by the name of Dyngja, reaches in Iceland nowhere such dimensions as in Ódádahraun, as for instance Kollótta-Dyngja, Trölladyngja, Kerlingar-Dyngja, Ketil-Dyngja. In some places many rows of craters are ranged together along rifts from north-east to south-west, as on Reykjanes, and in Dyngjufjöll, where the craters around Askja and along the slopes of the mountains are practically innumerable. In Odádahraun proper hardly any water is found; rain sinks through the lava, and emerges again from under its edges in many small rivers and springs. The southernmost portion of Ódázahraun has already been buried under glacial mud and sand from Vatnajökul, incessantly poured over its edge towards the north by innumerable glacial rivulets, that mostly vanish into the underlying sands and the lavas over which they are spread. Some of the larger streams, however, find their way eastward to Jökulsá in Axarfjörd, and a few into Skjálfandafljót. In consequence of the elevation of Odádahraun above the level of the sea, and of its waterless condition, it is a region almost barren of vegetation. On the drift-sand a few tufts of Elymus arenarius or stray specimens of Statice armeria and Cerastium alpinum may be found. Round the skirts of Odábahraun, where the water wells forth, a good deal of vegetation shows in some places, especially along the western fringes, in the valleys of Skjálfandafljot, where summer-pastures form the sheep-walks of the inhabitants of Bárbardal. On the eastern side of Odádahraun there are only two oases-Herdubreicarlindir and Hvannalindir, and here the vegetation is confined to the banks of springs, its most distinguishing feature being the Angelica archangelica, which grows in small clusters or bushes everywhere along the banks of the brooks. There occur likewise some species of the slighter kinds of willow, such as salix glauca, $S$. phyllicifolia, s. herbacea, as well as a few species of heather. Over the watered shingle-flats about Herdubreiøarlindir there are spread in parts red carpets of the lovely French willow-herb (Epilobium angustifolium). Insect life is very poorly represented, hardly anything being visible, save a few Diptera. To the south of Ódádahraun not a plot of grass is to be seen, except at Gasavötn, in Vonarskaro, where the vegetation is of the scantiest kind, comprising indeed little more than the Salix herbacea. Along glacial streams no sign of vegetation is ever apparent here; what little occurs grows along fresh-water springs.

It might be imagined that such a volcanic region as Odádahraun would be rich in hot springs, solfataras, \&c. But such is not the case. The main portion of the lava is now so old, that all such volcanic phenomena seem to have died out. Of warm springs only two may be said to be still in existence, both on the western side of the lava; yet they are only lukewarm (respectively $33^{\frac{1}{2}}$ and $35^{\frac{1}{2}}$ C.) About Gæsavötn such springs obviously once 
exi:ted, but they have now almost entirely vanished (their temperature having sunk to from $5^{\circ}$ to $7^{\circ} \mathrm{C}$ ). Dyngjufjöll, especially the valley of Askja, are the only localities in these regions, where volcanic manifestations of this character are now to be seen ; and there hot springs, claypits, sulphur-mines, and fumaroles of every kind are well developed. But these appearances are to be connected with an enormous eruption which occurred as late as 1875 Throughout the whole of Odázahraun I have come upon no traces of subterranean heat, except at the places here mentioned. About the peninsula of Reykjanes which I explored last year, many more signs of activity were found, which seems to show that in that locality the volcanic disturb inces are to be referred to a later period than those of Ódárahraun.

The northern edge of Vatnajökul has never been examined before. In my journey I was enabled to take the various elevations of this glacier, and found that at its western extremi $y$, in the ncighbourhood of Vonarskary, it rises to its greatest height, over 6000 feet. Fast of this point it becomes lower, until it rises again about Kverkfjoll, where an upheaval is perceptible right across it from north to south. From the hollow, or lowest point, the largest glacier in Iceland has taken its course. It is important that this glacier should be carefully examined, but its exploration would require a long time, for it is almost impossible to make a lengthered stay here, on account of the utter barrenness of the region, and the roughness of the weather.

In this journey 1 succeeded in solving the geographical riddle, which of the many rivers of Iceland is the longest. It has hitherto been assumed that Jokulsá in Axarfjörd was the longest, roo English miles; and that next to it came tjórsá, 96 miles long; but I have now ascertained that pjórsa is by far the longest river in Iceland, its course being about I 20 miles, while Jökulsá is only 95. Hitherto, also, it has been supposed that the sources of Jokulsa were situated in the spurs of Kistufell ; they are really twenty miles further to the east, under the western slopes of Kverkfjoll. The sources of Fjórsá are situated in the north-westerly portion of Sprengi andr, to the north-west of Fjóroungsalda. pjórsá, too, carries a greater volume of water than Jökulsá. On a July day the latter carries, midway betwcen its source and its mouth (viz. at Grimsstaðir) 14,500 cubic feet of water per second, but Djórsá at the proportionate point (at Tjórsárholt) carries 17,600 cubic feet in the same space of time.

Akreyri, September 7

TH. THORODDSEN

\section{AMERICAN SUMMER ZOOLOGICAL STATIONS}

$\mathrm{I}$ the United States there has been during the past ten years a great increase in the advantages for the study of zoology. Not only has this increase been manifested in the colleges, but also by the facilities for summer study at the sea-shorc. At present we have on the Atlantic coast five stations where there are facilities for students to carry on investigations. These laboratories are of two kinds-one where only the advanced student is allowed to study, the ollier in which any one manifesting a sufficient interest in Nature may be allowed a chance to work upon the marine animals; these latter are themselves divisible into two classes-one in which regular instruction is given, and the other where the student is supposed to study for himself under the direction of an efficient instructor.

The laboratory at Beaufort, North Carolina, connected with Johns Hopkins University, is intended as a place where students of the University, and somewhat advanced students from other colleges, can spend the summer in advanced work. It has attaincd for itself a reputation equalled by no other laboratory of its character in the country, because of the excellence of its work. Being supported by a regular fund, there are advantages connected with it which one will not find in other laboratories which are dependent upon subscriptions. Some excellent specialists spend their summers at this station, and the character of their work is shown in the bulletins published from the laboratory. Although Beaufort is not remarkably rich in variety of forms, still this is counterbalanced by the abundance of certain very interesting animals, for the study of which no better place than Beaufort can be found. As the Gulf Stream strikes on this coast, there are many interesting embryos found in the water. The building is a two-storicd house made to serve as a laboratory, and it is placed within a few feet of high-water mark. The location is a low sandy shore in a rather warm climate, but this is necessary on that coast where nothing else is found. For collecting purposes a steam-launch and sail-boat are used. It is under the direction of Prof. W. K. Brooks, who has done much towards making it what it now is.

Much further north, at Newport, Rhode Island, is another laboratory of a somewhat different character. It is under the charge of Prof. Alexander Agassiz, who, with a few assistants and some advanced students from Harvard College, carries on his investigations on the seashore. Dr. F. Walter Fewkes and C. O. Whitman study regularly at this laboratory. Because of its private character it should rather be classed with the former private laboratories which investigators were accustomed to establish at some favourite place on the sea-shore than with the general laboratories for students, though a certain limited number are admitted each summer. The advantages for study are limited, and the locality rather poor.

In the southern part of Massachusetts, at a place called Wood's Holl, the chicf marine station of the United States is stationcd. This is the Laboratory of the United States IFish Commission. Since 1871 the Fish Commission has each year been located at some point on the New England coast, investigating principally the specific characters of the marine fauna. Prof. Baird, the Commissioner, has had the direction of the Commission since it was first originated, and with the assistance of such eminent American naturalists as Goode, Bean, Verrill, Smith, and Sanderson Smith, the previously unkown New England fauma has been thoroughly studied, and certain parts of the North Atlantic deep sea carefully studied. For many years all the work has been done by specialists employed by Govermment, in a poorly adapted laboratory; but now a new building is bcing erected for the express purpose of serving as a laboratory, and it will be fitted up with all the modem conveniences for zoological and microscopical study. Being supported by an ample Government fund, it is expected that thcre will be a good library connected with it, and we know that there will be a supply of large aquaria, and that all necessary chemicals will be supplied. In addition to the tables for regular employées, there will be room for a limited number of students from some of the larger collcges, who will thus be offered the finest advantages for zoological study to be found in America. For the use of the laboratory there is a steam-launch, and many small boats, while the two steamers Albatross and Fizh Hawk are constantly bringing in material from the deep sea and surface of the ocean. Wood's Holl is excellently adapted for the purposes of a summer laboratory, both becausc of climate and variety and abundance of animal forms. The work already done from the old laboratory is of world-wide renown.

This ends the list of those laboratories intended solely for advanced students. Of the other class, the Summer Institute at Cottage City, Mass, is an example. This is a summer educational institution covering a wide variety of subjects, and intended for teachers who are willing to 